\title{
COSMÓPOLIS (1919-1922): ENTRE EL MODERNISMO Y LA VANGUARDIA
}

\author{
COSMÓPOLIS (1919-1922): BETWEEN \\ MODERNISM AND THE AVANT-GARDE
}

Juan PASCUAL GAY

Grupo de Investigación en Historia de la Literatura Hispánica

\begin{abstract}
Resumen: Cosmópolis (1919-1922) con frecuencia ha sido considerada por la crítica como una revista modernista. Desde luego, la temperatura literaria y cultural de la publicación obedece en parte a la sensibilidad finisecular. Con todo, pocas veces se ha subrayado el interés y la curiosidad que desde el principio mostró hacia la incipiente vanguardia en lengua española. No fue menor la convivencia con publicaciones marcadamente vanguardistas como Cervantes (1916-1920) y Grecia (1918-1920), que compartieron con Cosmópolis colaboradores y articulistas. Este texto pretende demostrar los estrechos vínculos de esta revista con la vanguardia hasta volverla una plataforma decisiva para su difusión.
\end{abstract}

Palabras clave: Revistas; Cosmópolis; vanguardia; modernismo; actualidad.

Abstract: Cosmópolis (1919-1922) has often been considered by critics as a modernist magazine. Of course, the literary and cultural temperature of the publication obeys in part to the finde-siècle sensibility. However, the interest and curiosity that from the beginning showed towards the incipient avant-garde in Spanish language has seldom been emphasized. It was not less the coexistence with publications markedly avant-garde as Cervantes (1916-1920) and Grecia (1918-1920), who shared with Cosmópolis collaborators and writers. This text aims to demonstrate the close links of this magazine with the avant-garde until it becomes a decisive platform for its dissemination.

Key words: Magazines; Cosmópolis; avant-garde; modernism; news. 


\section{$\mathbf{I}$}

\section{ntroducción}

Hablar de una revista, de cualquier revista, resulta un intento vano por detener un tiempo incesante; no sólo desde el momento puntual en que nos acercamos a ella, sino también cuando nos percatamos de esa sucesión que acota su vigencia. Más que frente al tiempo, las revistas nos devuelven la extraña experiencia de una temporalidad contradictoria y plural, algo semejante a una parálisis o suspensión a condición de que fluya inconteniblemente número a número, sección a sección, página a página. Una revista es un regreso a lo que ya pasó y se fue definitivamente pero también nos regala la sensación de asistir a unos acontecimientos como si fuera la primera vez. No es sólo la vuelta a ese pasado, sino más bien al presente de ese pasado o a su actualidad. Esa vigencia sólo se experimenta a condición de que aspectos significativos del pasado se rehabiliten en el ahora. Dicho de otra manera, el pasado se recupera en virtud de su valor de presente, una presencia vehiculada por la tradición. Y así como la tradición se ofrece en un momento particular a partir de la mirada de quien la actualiza, así también los significados de una revista en el presente están condicionados por esa idea de la tradición que opera en el curioso. De esta manera, el sentido de esa indagación histórica o arqueológica no sólo es parcial respecto de lo que verdaderamente supuso esa publicación durante el periodo en que circuló, sino también de los intereses que motivan su rescate. De alguna manera el valor parcial de ese pasado cobra sentido porque es significativo en alguno de sus aspectos en el presente. Es cierto, pues, que pueden proponerse clasificaciones o, más convenientemente, caracterizaciones de diferentes revistas desde el punto de vista de sus propuestas literarias y culturales; desde la nómina de colaboradores que congregan sus páginas; desde la voluntad colectiva o individual que las preside; etcétera. Pero no es menos cierto que involuntariamente algunas publicaciones gozan de un reconocimiento que sólo el tiempo concede. Porque, además de toda esta variedad, la historia termina por otorgar sentido y significado a determinadas empresas periódicas que las vuelven caso raro y excepcional, no porque en su momento fueran excepcionales, sino porque el tiempo imprime en ellas un singular marchamo que el presente reivindica.

Es precisamente esta singularidad la que distingue entre tantas cosas a Cosmópolis, gaceta que apareció en enero de 1919 y transitó con cierta comodidad hasta septiembre de 1922, año de su cancelación. Dirigida por el guatemalteco Enrique Gómez Carrillo, Cosmópolis se edita en Madrid y convive con otras publicaciones del momento como Cervantes (1916-1920) y Grecia (1918-1920), a las que sobrevive en dos años. Guillermo de Torre señala la distancia entre Cosmópolis y otras revistas del momento:

Sobrevienen luego las revistas que reclaman un apartado rigurosamente propio: las del movimiento ultraísta, iniciadas con Cervantes (1919), que paradójicamente en sus primeros tiempos fue un rezago modernista [...] seguida por Grecia (1919). Ésta también, curiosamente, tuvo en sus orígenes (pues apareció apadrinada por unos versos de Rubén Darío) rasgos muy diferentes de los que luego le dieron su verdadera fisonomía; y las más singulares, que se extienden de 1920 a 1924: Ultra, Tableros, Reflector, Horizonte, sin 
olvidar Alfar (1923) y Plural (1924). En un ángulo quedan, dentro del mismo período, otras importantes, mas con rumbos diferentes: Hermes, de Bilbao (1919) y Cosmópolis (1919) (1969: 63).

Así como las diferencias con estas publicaciones son evidentes, también lo es la deuda que Cosmópolis contrae con ellas. Los estudiosos han simplificado demasiado esta publicación, reduciéndola a una especie de epígono del modernismo. El crítico español Rafael Osuna afirma que estuvo «orientada hacia el modernismo periclitado, y muy poco hacia la vanguardia» (2005: 105). Posiblemente la urgencia por proscribir el modernismo se deba a Guillermo de Torre quien en Historia de las literaturas de vanguardia sitúa «los estertores del modernismo» entre 1915 y 1917, y un poco después afirma que en 1919 «la tendencia entonces dominante —el rubendarismo, ya estaba agotada» (2001: 513, 519).

Cosmópolis desde el principio dio cabida a textos y artículos sobre el arte nuevo, hasta constituirse en una extensión de la revista Grecia en cuyas páginas el ultraísmo adquirió carta de naturaleza. Sin embargo, a diferencia de Grecia, la curiosidad de Cosmópolis no se atuvo exclusivamente al ultraísmo, ni fue su plataforma en sentido estricto (Bonet, 2012). Es cierto que Cosmópolis se inscribe en el movimiento modernista o, para ser más precisos, finisecular, pero eso no impide que no estuviera alerta de cuanto acontecía en materia literaria y cultural. Sus páginas acogen con naturalidad no sólo ensayos y estudios sobre la nueva literatura representada por las vanguardias, sino también muestrarios de esa literatura, en particular de la poesía. Con todo, Enrique Gómez Carrillo dota de personalidad a una publicación que, sin desatender lo nuevo, privilegia la estética de fin de siglo. Así se reconoce en la reseña de la revista Cervantes que saluda al primer número de Cosmópolis, elaborada por Héctor que poco después recala en la redacción de ésta:

Cosmópolis. Núm. 1. Enero de 1919.- El espíritu andariego del admirable chornigueur Gómez Carrillo, fatigado sin duda de sus pintorescas andanzas, e iniciando su ocaso viajero, se aquieta ahora en España, y para hacer fecundo su remanso, funda esta revista mundial, que muy certeramente rotula Cosmópolis.

Bien nutrida y presentada, con una base de firmas prestigiosas españolas y extranjeras y orientada ideológicamente hacia Francia y las demás naciones latinas, se ha revelado Cosmópolis en su primer número como una magna revista española, capaz de proyectar en sus páginas, al igual que el Mercure de France, en París, las facetas mundiales más interesantes en sus diversas zonas políticas, ideológicas, estéticas, etc... (enero 1919: 187).

\section{Cosmópolis, una caracterización}

Acabada la Gran Guerra, Enrique Gómez Carrillo regresa a París. Poco después, en enero de 1919, aparece en Madrid el primer número de Cosmópolis, revista literaria y cultural fundada por Manuel Allende, dirigida por Enrique Gómez Carrillo, de periodicidad mensual y un tiraje de 10,000 ejemplares. Rafael Osuna describe con solvencia la revista, pero incurre en inexactitudes y errores (2005: 105-131). A partir del número 37, la dirección recae en el cubano Alfonso Hernández Catá. Cosmópolis alcanzó 44 entregas, cancelándose en septiembre de 1922. ${ }^{1}$ El número 33, correspondiente a septiembre de 1921, integra ya el subtítulo que se mantiene hasta el final: «Revista Mensual de

\footnotetext{
${ }^{1}$ Rafael Osuna consigna 45 entregas de Cosmópolis (2005: 105). En realidad, fueron 44, la última en septiembre de 1922.
} 
Literatura y Crítica». Como se lee en la portada inaugural, las entregas se tiraban en la Imprenta de Juan Pueyo, ubicada en la C/Luna, núm. 29, Madrid, cuyo concesionario era la Sociedad Española de Librería, situada en el número 21 de la madrileña calle de Ferraz. Cosmópolis invita a la suscripción a razón de 20 pesetas al año en España y 25 en el extranjero, con un precio por ejemplar de 2 y 2,5 respectivamente. En septiembre de 1920, la Redacción inserta un aviso en el número 21 que informa la subida del precio de venta y suscripción:

En menos de un año las huelgas han hecho subir el precio de la imprenta en un 70 por 100. El papel también ha subido en proporciones tales, que todas las publicaciones periódicas han tenido que aumentar su precio de venta y de suscripción.

Nosotros hemos resistido mientras hemos podido.

Hoy, inclinándonos ante la necesidad de no perder ya más de lo que hemos perdido, tenemos que decidirnos a un pequeñísimo aumento de 50 céntimos por número.

Cosmópolis se venderá, pues, desde hoy a 2 pesetas 50 céntimos, y la suscripción será de 30 pesetas al año (2).

La dirección remite cualquier correspondencia al secretario de la redacción, Alfonso de Sola, con domicilio en Calle de Alarcón, 14, Madrid, trasladándose más tarde a Plaza del Cordón, 1. J. M. Yagües se suma a la revista en agosto de 1920 como gerente. En septiembre de 1921, Guillermo de Torre toma el relevo de Sola como Secretario de Redacción. El diseño desmiente el nombre de la publicación. Revista de numeración corrida, cada entrega reúne alrededor de 200 páginas, con letra apretada y sin espacio entre líneas; a partir del número 37 reduce el número de páginas hasta las 80 . Sin apenas ilustraciones ni viñetas, las únicas variaciones al formato original se aprecian en la disposición gráfica del título mediante unos tipos que oscilan entre el gusto modernista y la vanguardia. El número 33 incluye por primera vez precio por espacios publicitarios: Una plana, 100 pesetas; Media plana, 75; Cuarto de plana, 50; y Octavo de plana, 25; lo que permite conjeturar que para esa fecha Cosmópolis adolece ya de problemas económicos que seguramente están en el origen de la reducción cuatro números después del número de páginas por entrega. Entre sus colaboradores cabe mencionar a los españoles Mauricio Bacarisse, Rafael Cansinos Assens, Rafael Lasso de la Vega, Manuel Machado, Luis Mosquera, Edmundo González Blanco, José Venegas, Marichalar, Eduardo de Ontañón, Goy de Silva, Luis Araquistáin, Eliodoro Puche, Adolfo Salazar, Miguel de Unamuno, César A. Comet, Guillermo de Torre, Alberto Insúa, Hernández Catá; entre los hispanoamericanos, a Gómez Carrillo, Luis Antonio Olmet, Rafael Lozano, Max Henríquez Ureña, Jorge Luis Borges, Alberto Guillén, Francisco A. Icaza, Blanco Fombona, Guillermo Jiménez, Manuel Maples Arce, Leopoldo Lugones; europeos fueron Apollinaire, D’Annunzio, Douchitch, Maurice Maetrelink, Blais Cendrars, Joseph Kessel, William Sarage, Jean Epstein, Paul Neuhuys, Clément Pansaers, Karel Capek, Elias Ehrenburg, Charles Roile, Maurie Rochet, etcétera. Entre estos, importa diferenciar a los autores europeos publicados en Cosmópolis como consecuencia de su política editorial y quienes se integran como colaboradores formales. Entre los primeros: Apollinaire, Gabrielle D’Annunzio, Maurice Maeterlink, etcétera; entre los segundos, William Sarage, Paul Neuhuys, Clément Pansaers, entre otros. La nómina de autores en que se interesaron los responsables de la gaceta es elocuente del gusto fin de siglo, pero también de la incipiente vanguardia que representan. Durante la dirección de Gómez 
Carrillo se mantuvieron las secciones que vuelven a Cosmópolis una publicación reconocible. Con la llegada de Hernández Catá, se acometieron modificaciones acordes con el recorte de presupuesto, así como con el interés de los colaboradores más asiduos.

\section{El nombre de la revista}

Juan Ramón Jiménez declaraba elocuentemente al comienzo de El Modernismo: «El movimiento modernista, no es una escuela; bajo el caben todas las ideologías y sensibilidades» (2010: 19). El nombre de la revista, Cosmópolis, es una declaración de intenciones que exhibe al principio su gusto modernista. Pero resulta que el cosmopolitismo, una actitud inseparable de la modernidad, impulsa los movimientos de vanguardia que surgen al cobijo de las posibilidades del fin de siglo. Y la vanguardia, por lo menos ciertas expresiones, tuvo cabida natural en la revista. Conviene detenerse en el título, Cosmópolis, nombre seguramente propuesto a iniciativa de Gómez Carrillo si se atiende a la devoción que sentía por esta palabra. En su autobiografía, Treinta años de mi vida, el guatemalteco reproduce una crítica de Leopoldo Alas, «Clarín», a Esquisses (1892), entonces recién publicada, con un aparente reparo hacia la francofilia del autor:

Si la noble tarea de Gómez Carrillo no es conducida con mucha prudencia, huyendo de extremos, con precaución y aun cautela, ¿no estará expuesta a favorecer esa disolución de lo español, de lo castizo, de lo nuestro? Sí, lo está; y como Gómez Carrillo no se ve libre por completo del vicio de que hablaba, su propaganda de cosmopolitismo literario, que desde el punto de vista de la noticia, de la información, es excelente, necesita correctivo por otro lado $(2011: 368) .^{2}$

Pero Clarín no se limita a señalar el cosmopolitismo como directriz del temperamento de Gómez Carrillo, sino que precisa un poco más al distinguir entre «parisiense» $\mathrm{y}$ «cosmopolita»: «dentro de lo parisiense hay la especie de lo parisiense que se cree cosmopolita, artístico, libre de preocupaciones burguesas, sin lazos prosaicos con lo natural ordinario» (Gómez Carrillo, 2011: 368) . El asturiano subraya la disolución de lo nacional o lo hispánico en Gómez Carrillo, algo que éste se tomó como un reconocimiento. Poco después el español asocia cosmopolitismo con universalismo (de la Fuente, 2009: 22-27). Sin embargo, hacia 1900 el vocablo se vinculaba con exotismo, como Cansinos Assens indica: «La crónica de París de nuestros corresponsales ha perdido ya el exotismo que tenía en tiempos de Gómez Carrillo» (1998: 113); o como insinúa López Lapuya: «Carrillo constituye una mentalidad europea, vestida con ropaje en momentos extraño» (2001: 165). Desde ese momento, cosmopolitismo se asoció en España con Gómez Carrillo, operando como sinónimos o como términos intercambiables. No por casualidad, el guatemalteco, en 1894, había publicado Literatura extranjera. Estudios cosmopolitas en la parisina Garnier Hermanos. En las primeras décadas del siglo XX, lo moderno en detrimento del exotismo se relaciona con lo cosmopolita.

La actualidad de Cosmópolis reside no sólo en que se ofreció para publicar poemas y narraciones, artículos y ensayos vanguardistas o de estirpe vanguardista, sino que a la vez publicó textos de ambigua

\footnotetext{
${ }^{2}$ El autor publicó en la revista sucesivamente fragmentos de su autobiografía en Cosmópolis: “Treinta años de mi vida", en los números de febrero de 1920, marzo de 1920, abril de 1920, mayo de 1920, junio de 1920 y julio de 1920.
} 
adscripción literaria. Alentó, además, la pluralidad y heterogeneidad de los colaboradores. Es decir, fue una revista cosmopolita dirigida en su momento a un público exigente capaz de reconocerse en sus páginas. El término cosmopolita concentra significados diversos, en ocasiones relacionados con lo sofisticado y elegante; en otras, con lo universalista y mundano; otras más, con la pervivencia finisecular de lo exótico y extraño. Siempre, no obstante, refiere una moralidad en oposición a otras. El vocablo ha estado presente en la cultura occidental al menos desde la escuela cínica para la que «cosmopolita» se decía del «ciudadano del mundo». Para Diógenes, el hombre debía proponerse vivir como un perro, rechazando aquellos valores adoptados por la sociedad que se desviaban de la verdad. El cosmopolitismo se opone desde el principio a los límites de una comunidad para constituirse en una supra comunidad, por encima de diferencias locales y nacionales. Este ideario impulsó la noción de Weltiteratur de Goethe o la liga de naciones de Kant. Christoph Martin Wieland compendió este ideal:

Los cosmopolitas [...] ven a todos los pueblos de la tierra como otras tantas ramas de una familia única, y al universo como un Estado, del cual ellos, junto con otros innumerables seres racionales, son ciudadanos, a fin de promover la perfección del todo de acuerdo con leyes generales de la naturaleza, mientras cada uno, a su manera, se ocupa de su bienestar (Appiah, 2007: 17).

El cosmopolitismo establece vínculos que sobrepasan los estrictamente familiares y próximos, y a la vez subraya el interés que merece cualquier vida por ajena o extraña que sea, así como la sociedad en que se presenta. Es cierto que el vocablo se ha contaminado de matices peyorativos debido a la supuesta superioridad del cosmopolita frente a lo provinciano. Indudablemente los artistas e intelectuales son más permeables a una actitud universalista por la propia materia con la que trabajan; más atentos a las transformaciones procedentes de otras geografías y otras lenguas; más receptivos ante las propuestas ajenas. Si el cosmopolitismo es una manera de estar en el mundo, los intelectuales resultan particularmente sensibles para adquirir esa ciudadanía. Paul Hazard indica que el término «cosmopolita» irrumpe en el siglo XVIII con unos significados precisos: «el cosmopolita [...] entraba en una tribu, formaba parte de una especie, era también ciudadano de una nación, de una nación que comprendía a los civilizados de todas las naciones y cuyos miembros se sentían unidos por una comunidad de lenguaje y aun de vida» (1946: 428). Desde el siglo XIX se asoció el término con el viaje: en un primer momento, el exotismo operó como sucedáneo, pero poco después el viaje mismo se volvió asunto literario hasta promover todo un género (Litvak, 1986; Pritchett, 2011). Un momento señero fue la publicación en 1878 de Karl Baedeker de su guía de París, un manual detallado y preciso de la Ciudad Luz y de las formas y maneras que el viajero curioso debía exhibir. No es posible disociar el cosmopolitismo finisecular del modernismo como corroboraba Rubén Darío al decir que «tuvimos que ser políglotas y cosmopolitas y nos comenzó a venir un rayo de luz de todos los pueblos del mundo», para reafirmarse poco después al referir «el soplo cosmopolita» que alentó al modernismo (Phillips, 1959: 53, 58). Gómez Carrillo publicó en Cosmópolis el ensayo «La psicología del viaje», en el número 12 de diciembre de 1919, en que defendía un cosmpolitismo amenazado en esos momentos por los nacionalismos: 
Ellos [psicólogos, filósofos, moralistas] eran, sin embargo, os que ayer nos aseguraban que el único medio de conocer a los pueblos lejanos y de establecer corrientes de simpatía cosmopolita consiste en establecer relaciones directas con los países extranjeros. [...] Pero hoy, a causa del triunfo absurdo y natural del nacionalismo literario, hijo de la guerra y de las alianzas, ya no nos dicen eso, sino que, casi, casi, nos dicen lo contrario... (610).

En el mismo texto, establece el propósito de sus traslados: «Por mi parte, yo no busco nunca en los libros de viaje el alma de los países que me interesan. Lo que busco es algo más frívolo, más sutil, más pintoresco, más poético y más positivo: la sensación. Todo viajero artista, en efecto, podría titular su libro: sensaciones» (612).

El cosmopolitismo modernista representó una irrupción que en el primer cuarto del siglo XX no hace sino reconfigurarse para adaptarse a cada circunstancia. El término rehabilita el magisterio de Baudelaire que prefiere utilizar la fórmula «hombre de mundo» pero a la que convienen los rasgos del cosmopolita: «Hombre de mundo, es decir hombre del mundo entero, hombre que comprende el mundo y las razones misteriosas y legítimas de todas sus costumbres». Y establece una distinción con el artista al que califica de «especialista, «brutos muy hábiles, puros braceros, inteligencias de pueblo, cerebros de aldea», en contraposición con «el hombre de mundo», «ciudadano espiritual del universo» (2005: 356). Rafael Osuna inserta el fragmento de una carta de Gómez Carrillo, extraído de la obra de Domingo Paniagua, Revistas culturales contemporáneas, en que se lee:

Para mí [...] España y América forman un solo imperio espiritual. Desgraciadamente, los españoles conocen tan mal América, que Baroja ha podido llamarla el continente estúpido. Y los americanos conocen tan mal a España, que muy a menudo la calumnian. Pero predicar el hispanoamericanismo a la manera de los señores del Ateneo y de los ateneos, es una labor vana, vaga y hasta algo ridícula. Hay que practicarlo. No hay que decir: "Tras los mares hay unos grandes poetas". Hay que traerlos, como hay que llevar a los de aquí a todos los pueblos que hablan la misma lengua.

Yo querría hacer eso. Yo querría que en las 200 páginas mensuales de mi Cosmópolis colaboraran los mejores de España con los mejores de América, para que viéndonos juntos, se dieran cuenta de que son individuos de la misma raza, hijos de los mismos padres, soñadores de las mismas quimeras... (2005: 106).

\section{Elementos cosmopolitas de la revista}

De manera que la revista de Gómez Carrillo, Cosmópolis, venía a reunir la mejor tradición occidental de los hombres de letras del siglo XIX, adoptada por el modernismo, y plenamente adaptada a la modernidad de las vanguardias. En rigor, la palabra misma no discrimina a condición de que quienes se reconocen en ella lo hagan como ciudadanos del mundo. La misiva del guatemalteco no olvida referirse a la aristocracia arielista, fundamentada en este caso en la misma lengua, el español. Quizás por este motivo, la orientación de la revista no privilegió a unos movimientos literarios sobre otros; al modernismo por encima de las vanguardias o al revés; sino que bajo el acuerdo de esa civilidad diferentes corrientes coincidieron y convivieron en sus 44 números. Por otro lado, nada más natural que su director diera cabida en las páginas de Cosmópolis a sus compañeros modernistas y que, de alguna manera, recibiera con reticencias a una vanguardia que apenas despuntaba. Pero si fue así, venció sus reparos como indica el hecho de que nombrara Secretario de Redacción a Guillermo de Torre quien desde antes había colaborado con la sección «Literaturas novísimas», en donde, como él 
mismo declara, «fueron apareciendo algunos estudios que luego - revisados, ampliados- formarían mis Literatura europeas de vanguardia» (2001: 546).

La publicación estuvo orientada a los gustos e inclinaciones en materia literaria y cultural de su primer director, pero no fueron privativos a la hora de exhibir otros intereses. César González Ruano recuerda al guatemalteco en París hacia 1925, una vez pasada la aventura de la revista, mientras éste evoca a Paul Verlaine, Maurice Maeterlink, Rémy de Gourmont, Jean Moréas, etcétera, ${ }^{3}$ para concluir que Enrique Gómez Carrillo «quizá le ocurría como a su literatura, que quedaba un poco boulevardier, un poco demasiado a la ligera, pero por eso mismo no pesaba y a su lado transcurría el tiempo sin sentirlo» (2004: 143). Cosmópolis incluyó en el número 1, enero de 1919, el artículo «Gómez Carrillo, juzgado por Maeterlink», en que el belga levanta el mapa estético y moral del guatemalteco:

Sabe pintar un paisaje, una ciudad, un palacio, como Teófilo Gautier; pero alcanza además a poblarlos, y en él el mármol y el bronce no aplastan a los hombres. Es a veces risueño, familiar y exuberante, como Dumas padre; pero se ve que su imaginación está siempre al servicio de la más estricta verdad. Cuando hace falta muéstrase preciso, meticuloso, narrativo y gráfico, como Stendhal; especulativo y documentado como Taine; fatalista sombrío, pictórico, melancólico y vago, como Loti; sensitivo, soñador y sutil, como Gerardo de Nerval; ergotista, combativo, práctico y moderno, como Julio Huret, de quien tiene la ojeada pronta y despiadada y la frase instantánea (160).

Guillermo de Torre escribe que Cosmópolis era una «revista dirigida a un público más general», pues Gómez Carrillo «ambicionaba, un poco tardíamente, hacer de tal publicación un Mercure de France español» (2001: 545-546) ${ }^{4}$. Las secciones más o menos fijas de la revista durante la dirección de Gómez Carrillo fueron, entre otras, «Estudios cosmopolitas», «Las figuras del día», «La vida femenina», «Fisonomía de ciudades», «Crónica de Italia», «Crónica de París» y «Crónica americana»; subtítulos que exhiben esa sensibilidad modernista asociada con lo cosmopolita, pero sobre todo con el género preferente del guatemalteco, la crónica. No por casualidad Gómez Carrillo publicó en el primer número de Cosmópolis «La escuela de periodismo», en que cifra aquello que considera imprescindible para ejercer el oficio:

Ser un animador, he ahí lo principal para quien se consagra a escribir, día por día, en hojas que duran exactamente lo que las rosas. En el libro y en la revista, puede que otras cualidades sean más necesarias. En el periodismo nada es comparable al don de dar nociones rápidas y exactas de la vida que pasa, con todo lo que tiene de exterior y de íntimo, de patético y de profundo; con lo que es en ella espectáculo, problema, idea, misterio, drama, farsa; con su formidable palpitación multiforme y con su serena evolución invariable;

\footnotetext{
${ }^{3}$ En las sección "Antología francesa", Cosmópolis publicó traducciones de poemas de autores simbolistas y finiseculares: "Seis poemas inéditos de Oscar Wilde", 1 (enero de 1919): 142-152; "Poesías de Mallarmé", 2 (febrero de 1919): 342346; "Poesía de Jean Moréas", 3 (marzo 1919): 562-566; "Poesías de Francis Jammes", 4 (abril de 1919): 660-663; "Poesías de Albert Samain", 5 (mayo de 1919): 110-112; "Poesías de Arthur Rimbaud", 6 (junio de 1919): 295-297; "Maurice Maeterlinck", 8 (agosto de 1919): 690-693; "Emile Verhaeren", 9 (septiembre de 1919): 43-48; "Georges Rodenbach", 11 (noviembre de 1919): 416-421; "Charles Guérin", 12 (diciembre de 1919): 634-638; "Charles van Lerberghe", 14 (febrero de 1920): 117-120; "Stuart Merrill”, 15 (marzo de 1920): 257-259; "Jules Laforgue", 16 (abril de 1920): 432-436; "Tristan Klingsor", 17 (mayo de 1920): 24-27; "Paul Verlaine”, 18 (junio de 1920): 247-260; "Edmond Rostand", 19 (julio de 1920) 457-466; "Francis Viélé-Griffin", 20 (agosto de 1920): 606-609. A partir del número 21 la sección pasó a llamarse "Antología" y suele repetir poesías de autores ya publicados. Pero se retoma un poco después también con largas interrupciones: "Jean Richepin", 24 (diciembre de 1920): 771-776; "Charles Baudelaire", 34 (octubre de 1921): 321-326; 35 (noviembre de 1921): 392-394.

${ }^{4}$ Gómez Carrillo había dirigido en 1907 la revista Nuevo Mercurio.
} 
con lo que enseña y con lo que inquieta; con lo que sonríe y con lo que llora; con lo que es fugaz, y con lo que es eterno (115-116).

Los colaboradores de cada sección, a excepción de «La vida femenina», a cargo de la Marquesa de Cespón, variaban según las necesidades o intereses de la publicación. Así se presenta «La vida femenina» en el número 2 de febrero de 1919: «La marquesa de Cespón, que durante largos años escribió para La Nación, de Buenos Aires, crónicas parisienses sobre la vida femenina y llegó a ser considerada justamente como una de las escritoras más eminentes en su género, hablará cada mes a nuestras lectoras de lo que más interesa al bello sexo» (232). La sección «Las figuras del día» inauguraba la revista, ya en el primer número de enero de 1919, precedida de la siguiente nota:

En esta sección, que será al propio tiempo un camposanto para enterrar a los grandes muertos del mes y una avenida triunfal para ver pasar a los vencedores en los combates de la política, de las artes, de las ciencias, trataremos siempre de dar preferencia a las páginas más personales y más íntimas. Entre una biografía completa y una silueta vivaz, aunque fragmentaria, preferiremos siempre esta última (168).

Un aviso en el número 2 en febrero de 1919, indicaba el sentido de «Crónica americana»: «En esta sección que abrimos en Cosmópolis registraremos, mensualmente, las principales manifestaciones de la vida americana, a fin de cumplir uno de nuestros más importantes objetivos, que es el de favorecer el mutuo conocimiento entre España y los hermosos países del Nuevo Mundo» (315). «Crónica de Italia» concentró colaboraciones de Leonardo Marini, mientras que «Crónica de París» alternaba las firmas de J. Martel, Rafael Lozano, Enrique Gómez Carrillo etcétera. «Notas cosmopolitas» daba cuenta de diversos episodios culturales, políticos y sociales acontecidos en diferentes países europeos y era firmada por las plumas más dispares. La ciudad ocupó en Cosmópolis un espacio reconocible como metonimia de la modernidad y el progreso, del cosmopolitismo y la pluralidad, a la que dedicó varias secciones y colaboraciones. Así, «Fisonomías de ciudades después de la guerra», cuyo propósito se recoge en las palabras que preceden a la colaboración que inaugura esta sección en el número 2, en febrero de 1919:

Nada tan interesante como el aspecto de las capitales de los países beligerantes y de las ciudades en general de esas mismas naciones, después del conflicto mundial, según que hayan pasado por la derrota, por la revolución o por la victoria. La guerra ha cambiado el verdadero carácter que mil veces les habían atribuido viajeros y cronistas, porque ha modificado profundamente sus alegrías, sus esperanzas y su porvenir. Por esto nos parece que nuestros lectores verán con gusto un somero estudio de estas ciudades que refleje el aspecto actual (354).

Pero también atiende a diferentes países de América Latina como las crónicas de «El Uruguay» firmada por Fernández Medina, en el número 3 de marzo de 1919; «Cuba en 1919», por García Kohly, aparecido en la cuarta entrega en abril de 1919; «Guatemala en 1914» rubricada por Juan J. Ortega y publicada en el número 5, en mayo de 1919. Cosmópolis también cede páginas para retratar ciudades europeas, así la colaboración de José Nogales en el número 10, octubre de 1919, «El encanto de Sevilla»; o el anónimo «Venecia y sus pintores», en diciembre de 1919, correspondiente a la entrega 12. 
A partir del quinto número, en mayo de 1919, la revista habilitó la sección «Estudios cosmopolitas», que se sumó a «Notas cosmopolitas» presente desde el inicio, dedicada en este caso a «La literatura norteamericana» y que volvió a acaparar la atención del número 11, en noviembre de 1919, en ambos casos a cargo de Vincent O’Sullivan; en el número 6, Paul Loewengard firmó «Renacimiento de la literatura judía»; en julio de 1919, la séptima entrega incluye un artículo de William Spet, «La literatura belga»; «El movimiento literario en Hungría», firmado por Andrés Révész, aparece en el número 9, septiembre de 1919; Maurice Gauchez rubrica en el número 11 «a poesía nueva en Bélgica»; en el 16, abril de 1920, F. Hoggan «La literatura y el arte negros»; una entrega después A. P. colabora con «La literatura provenzal»; Demetrius Asteriotis publica «El nuevo helenismo» en el número 18 correspondiente a junio de 1920; un anónimo firma «La nueva literatura alemana», en el número 19, en julio de 1920, que se prolonga en agosto y septiembre de ese año. A partir del mes de octubre la sección se desfigura y pierde peso en la gaceta, aunque su espacio no desaparece del todo, asumido por «Notas cosmopolitas». Posteriormente, ya bajo la dirección de Hernández Catá, la sección pasó a llamarse «Letras extranjeras», cuya primera contribución fue «La nueva poesía en Bélgica» rubricada por Paul Neuhuys, publicada en el número 40, abril de 1922.

Entre el 27 de enero de 1921 y el 15 de marzo de 1922 apareció Ultra, revista del movimiento vanguardista al que debe su nombre, cuyo manifiesto había sido redactado en 1919 por el incipiente grupo de vanguardistas integrado por Rafael Cansinos Assens, José Rivas Panedas, César A. Comet, Pedro Garfias y Guillermo de Torre. La revista fue reseñada por Héctor para Cosmópolis, en el número 29 de mayo de 1921, quien subraya que «Esta es la revista que desde su primer número ha suscitado más amplia expectación y resonancia, visible en múltiples glosas periodísticas y constantes comentarios públicos», para concluir que en torno a sus páginas «se agrupan los jóvenes poetas ultraístas, desplegando el arco-iris de sus lirismos y teorizaciones movimorfas» (169-170). También lo fue Reflector, contemporánea de Ultra y Cosmópolis e igualmente reseñada por Héctor en la misma colaboración:

A nosotros, a Cosmópolis, que con Cervantes y Grecia, fue la primera Revista española en acoger las primicias de esta modalidad ultra-novecentista, tócanos hoy saludar jubilosamente la aparición del primer número de Reflector, que condensa los hallazgos y suma los elementos más valiosos de la joven generación ultraísta (170).

El antecedente inmediato de Ultra, Grecia (1918-1920), podría considerarse también de Cosmópolis, puesto que al poco de iniciarse cambió de orientación relegando las directrices modernistas en favor de lo nuevo y moderno. Isaac del Vando Villar, director de Grecia, había publicado en el número 20, correspondiente al 30 de junio de 1919, el «Manifiesto ultraísta» con el que daba por constituido el movimiento subrayando la novedad que representaba: «Los ultraístas estamos situados en la vanguardia del Porvenir; somos eminentemente revolucionarios y aguardamos impacientes la hora en que los hombres de ciencia, los políticos y demás artistas estén de acuerdo con nuestras rebeldías para proclamar, de una manera definitiva, el triunfo del ideal que perseguimos» (9) . En el primer aniversario de Grecia, el 12 de octubre de 1919, el mismo autor publica «El triunfo del 
ultraísmo» en que establece las deudas contraídas con la revista: «Grecia, por su ultraísmo y su modernidad - nos escribe Marinetti- nos interesa literariamente más que La Esfera, donde se publica tanta ordinariez, que revelan el mal gusto de su director, que es un verdadero verdugo de los poetas que tienen talento y cosas transcendentes que decir» (2). Meses antes, en mayo de 1919, Pedro Garfías había entregado «La fiesta del Ultra» en Cervantes, una exaltación del movimiento vanguardista hispánico a propósito de «una velada organizada por la redacción de la revista Grecia» en Sevilla, en donde se leyeron poemas de Guillaume Apollinaire, Rafael Cansinos Assens, Adriano del Valle, Romero Martínez, Isaac del Vando Villar, Pedro Raida, Pedro Garfias y Manuel González Olmedilla (76). La última entrega de Grecia, correspondiente al número 50 en noviembre de 1920, publicó en hoja suelta el manifiesto «Vertical» de Guillermo de Torre, futuro secretario de redacción de Cosmópolis, donde consigna que «el arte nuevo apellídase ultraísta, creacionista, cubista, futurista, expresionista, comienza allí donde acaba la copia o traducción de la realidad aparente: allí, en aquel plano ultraespacial donde el poeta forja obras inauditas y creadas que no admiten confrontación exterior objetiva» (s. p. $)^{5}$. Así, para Guillermo de Torre, cualquier manifestación plenamente moderna no era sino expresión vanguardista. El manifiesto fue reseñado en el número 23 de Cosmópolis por Rafael Lasso de la Vega, en noviembre de 1920, quien resume la propuesta:

En la perspectiva meridiana del sol perpendicular, Guillermo de Torre recoge, en un "índice de sensaciones, visiones y cerebraciones", las antifilosofías automáticas del libre circuito mental. Y en su trayectoria hacia el vértice del "simultaneísmo nunista", Torre descubre una nueva planimetría estética y fija su actitud verticalista.

Si el Arte fue antes cazar pájaros para exhibirlos tras las doradas barras de una jaula artificial, hoy fabricamos aves multiformes que lanzamos al espacio, para que con sus propias alas vuelen a su capricho, hasta desaparecer de nuestro radio visual.

Automatismo: El mundo es un laboratorio para el artista taumaturgo: alquimia Rimabaudiana, creación pura y electrolisis integral.

Vertical: Guillermo de Torre - nuestro más joven, culto y apasionado pionner ultraespacial- ha lanzado sobre la planitud amorfa de la literatura actual una gavilla de luminarias teóricas que sintetizan nuestros genuinamente contemporáneos móviles directrices (551-552).

\section{Cosmópolis y la nueva literatura}

Cosmópolis desde el primer número da cabida a la nueva literatura con dos ensayos significativos: el primero, firmado por Guillaume Apollinaire, «El espíritu nuevo y los poetas»; y el segundo, a cargo de Rafael Cansinos Assens, «Vicente Huidobro y el creacionismo». Apollinaire, en «El espíritu nuevo y los poetas», publicado en el número 1 de enero de 1919, indaga en las relaciones entre las diferentes artes a raíz de las innovaciones tipográficas que promueven el ut pictura poesis horaciano:

\footnotetext{
${ }^{5}$ Este manifiesto fue glosado por Rafael Cansinos Assens, "Vertical: Manifiesto ultraísta por Guillermo de Torre", en la revista Cervantes, diciembre de 1920, quien concluye de manera elocuente: "la actitud vertical es aquella de la que se deducen los cuatro puntos cardinales y las cuatro sombras que viajan en torno a la estatua inmóvil, es la condición primera que se requiere para orientarse y para engendrar en rotaciones sucesivas el poliedro total, y en este sentido está bien como actitud inicial de un poeta joven"(121).
} 
La asonancia, la aliteración, al igual que la rima, son convenciones que, aisladamente, tienen su mérito. Los artificios tipográficos, en lo que se ha realizado audaz avance, tienen la ventaja de hacer nacer un lirismo visual que era desconocido antes de nuestra época. Estos artificios pueden aún ir muy lejos y consumar la síntesis de las artes, de la música, de la pintura y de la literatura (18).

El francés diagnostica la pujanza del cinematógrafo como inspiración para una poesía hecha de imágenes, pero no abandonada a la anarquía poética de los «futuristas italianos y rusos, porque Francia repugna el desorden. Se aceptan los principios, pero se siente el horror del caos» (19). Apollinaire defiende un arte nuevo que no abdique de su carácter nacional, mediante una contradicción irresoluble: «Así el espíritu nuevo que ambiciona encarnar el espíritu universal y que rechaza los límites a su actividad, es una expresión particular y lírica de la nación francesa, como el espíritu clásico fue por excelencia una expresión sublime de la misma nación»(20). Paradójicamente, el francés asocia cosmopolitismo con francofilia como la expresión más ajustada del universalismo. No duda en registrar la influencia decisiva de Francia en la literatura de los demás países:

Los franceses llevan la poesía a todos los pueblos. A Italia, donde el ejemplo de la poesía francesa ha dado impulso a una joven escuela soberbia de audacia y de patriotismo. A Inglaterra, donde el lirismo se había estragado y casi agotado. A España, sobre todo a Cataluña, donde toda una juventud ardiente, que ya ha producido pintores que honran a las dos naciones, sigue con atención las producciones de nuestros poetas. A Rusia, donde la imitación de la poesía francesa ha dado a veces lugar al enrarecimiento. A la América latina, donde los jóvenes poetas comentan con pasión sus antecesores franceses. Y por último, a la América del Norte, a la cual, en agradecimiento a Edgar Poe y a Walt Whitman, misioneros franceses han llevado durante la guerra el elemento fecundador, destinado a dar una producción nueva, de la cual no podemos aún formar idea (26-27).

Por otro lado, constata que la nueva poesía debe vincularse al conocimiento, aun a riesgo de parecer ridícula, puesto que la investigación misma procura nuevos ámbitos de expresión y sentido:

[...] el lirismo no es más que un campo del espíritu nuevo en la poesía de hoy, que se conforma con rebuscar, con investigaciones sin preocuparse de darles significación lírica. Son materiales que amasa el poeta, que reúne el espíritu nuevo, y estos materiales formarán un fondo de verdad, cuya sencillez, cuya modestia no deben despreciarse, porque sus consecuencias, sus resultados pueden ser muy grandes (21).

El arte nuevo es así inseparable del progreso, aunque no lo condiciona, puesto que lo nuevo reside en la sorpresa; «el espíritu nuevo está todo en la sorpresa» (22).

La sorpresa es el hallazgo de la novedad artística en cualquiera de sus manifestaciones: «La sorpresa es el más gran nuevo resorte. Por la sorpresa, por la importancia que concede a la sorpresa, el espíritu nuevo se distingue de todos los movimientos artísticos y literarios que le han precedido» (2324). Finalmente, consigna los rasgos distintivos del arte nuevo:

El espíritu nuevo es, ante todo, enemigo del estilismo, de las fórmulas y de todo servilismo. No lucha contra ninguna escuela, porque no quiere ser una escuela, sino una gran corriente de la literatura que los englobe a todos desde el simbolismo al naturalismo. Lucha por el restablecimiento del espíritu de iniciativa, por la clara comprensión de su tiempo y por abrir nuevos horizontes sobre el inmenso interior y exterior, que no sean inferiores a los que los sabios de todas categorías descubren a diario y de los cuales obtienen maravillas (27).

El texto de Cansinos Assens sobre Huidobro parece alentado por estas palabras de Apollinaire: «Es que poesía y creación no son más que una misma cosa; no puede llamarse poeta sino al que inventa, 
al que crea en la medida que el hombre puede crear» (24). En efecto, Cansinos colaboró con «Un gran poeta chileno, Vicente Huidobro y el creacionismo» en la primera entrega de Cosmópolis. El ensayo reivindica la imagen del chileno, después de una estancia en París, que llegó a Madrid en el verano de 1918 entre la indiferencia de la prensa cultural: «Aquí fueron el silencio y la sombra las armas con que los intereses creados de nuestra literatura se defendieron contra el innovador», a pesar de que «su venida a Madrid fue el único acontecimiento literario del año, porque con él pasaron por nuestro meridiano las últimas tendencias literarias del extranjero; y él mismo asumía la representación de una de ellas, no la menos interesante, el creacionismo» (68-69). El autor de La novela de un literato no olvida referir a Pierre Reverdy como influencia decisiva para el movimiento de Huidobro. Cansinos Assens subraya la novedad de la poesía de Vicente Huidobro y censura el hecho de que su recepción en España fuera semejante a la que había recibido Rubén Darío. De esta manera, ubicaba la renovación literaria de la vanguardia tanto en América Latina como en París. No puede menos que sospecharse que el texto debió de estar sugerido o secundado por Gómez Carrillo, representante cabal de la estirpe de escritores hispanoamericanos asentados en París ${ }^{6}$.

Respecto de la revolución poética impulsada por el creacionismo, Cansinos en el ensayo referido inserta una cita de Horizon Carré (1917) que, en su opinión, concentra la novísima estética: «Crear un poema tomando a la vida sus motivos y transformándolos para darles una vida nueva e independiente. Nada anecdótico ni descriptivo. La emoción ha de nacer de la única virtud creadora. Hacer un poema como la naturaleza hace un árbol» (69). Cansinos Assens comenta a continuación: «Inútil negar la originalidad de este anhelo artístico, que si, como toda cosa, tiene su precedente remoto en el pensamiento de los hombres, no reconoce antepasados inmediatos» (69-70). Sin embargo, el español no se limita a insistir en la novedosa propuesta sino que la asocia con la modernidad, con el temperamento literario moderno, con una estética acorde con las exigencias de la actualidad que, como toda revolución, cancela lo anterior: «Porque si Rubén vino a acabar con el romanticismo, Huidobro ha venido a descubrir la senectud del ciclo novecentista y de sus arquetipos, en cuya imitación se adiestran hoy, por desgracia, los jóvenes, semejantes a los alumnos de dibujo, que se ejercitan copiando manos y pies de estatuas clásicas» (72). El diagnóstico prescribe unos modelos literarios exhaustos a finales de la segunda década del siglo XX, requeridos de una renovación a riesgo de convertirse en epígonos. Cansinos Assens advierte en el creacionismo de Huidobro un revulsivo ajustado no sólo para recuperar el ímpetu literario sino también para renovar una expresión poética que no podía permanecer indiferente ante las propuestas vanguardistas. La vanguardia ya no se contenta con figuraciones o desfiguraciones de la naturaleza, sino que ofrece otra nueva: «La nueva lírica, no sólo la que se vincula en el nombre de creacionismo, sino, en general, aquella cuyas floraciones arrancan de Guillermo Apollinaire y hoy se ilustra con los nombres de Reverdy, Allard, Frick, Cendras, etc., aspira a darnos

\footnotetext{
${ }^{6}$ Meses después estalló la polémica entre Gómez Carrillo y Huidobro, seguida puntualmente por la revista Grecia, pues el guatemalteco atribuyó la paternidad del creacionismo a Reverdy, relegando la importancia del chileno quien "en una actitud plañente, en esos días recorrió las Redacciones de los diarios más importantes para que le publicasen las cuartillas en donde de una manera violentísima y con una sintaxis ambigua replicaba a Gómez Carrillo, cosa que no pudo alcanzar", en Anónimo, "Panorama ultraísta", Grecia, 48 (1 de septiembre de 1920): 15.
} 
una representación íntegra, desapasionada, de la naturaleza, en estilizaciones de una desconcertante variedad» en que se aprecia tanto «la técnica mordiente y certera de los caricaturistas», como «una filiación pictórica» vinculada con «los modernos cubistas y planistas» (72). Finalmente, Cansinos concilia juventud con arte nuevo, concediendo a la edad los valores asociados al progreso y a lo moderno, a lo actual y a lo nuevo, irrumpiendo como otro factor necesario para la vanguardia: «Los jóvenes que rodearon a Huidobro durante su estancia aquí, supieron discernir la novedad alboreante de sus poemas. Leyéndole, volvían a sentir otra vez la inquietud de los novicios y poco a poco ensayaban el tránsito de sus jóvenes estrofas, ya viejas a las novísimas cristalizaciones» (73).

Estos dos artículos son relevantes puesto que certifican la curiosidad de Cosmópolis por las vanguardias ya desde el primer número, sin esperar a la incorporación de Guillermo de Torre a la secretaría de redacción. Más todavía si se repara en que, en diciembre de 1919, Gerardo Diego leyó en el Ateneo de Bilbao la conferencia «La poesía nueva», en que reconoce el legado del futurismo de Marinetti, el dadaísmo de Tzara y el esprit nouveau de Guillaume Apollinaire, como precursores del ultraísmo (2014: 58-60). Más significativa es la repercusión de estos movimientos en la poesía española de la hora:

¿Y en España? La renovación novecentista (vulgar e impropiamente llamada modernista) nos trajo un tanto retrasadas las direcciones de los credos parnasiano, decadente y simbolista. Pero antes de la guerra el anhelo de reacción contra las formas manoseadas y agotadas de estos poetas se empezó a mostrar en la obra compleja, desinteresada y humorística de Ramón Gómez de la Serna, así como en las meridionales cosechas de imágenes que colman las páginas grávidas de la prosa bíblica de Cansinos Assens. Sin embargo, en la Poesía permanecíamos estacionados. La llegada a España el pasado año del poeta chileno Vicente Huidobro fue en este sentido una revelación. Él nos trajo como frutos exóticos las últimas transmutaciones taumatúrgicas de las jóvenes escuelas (Diego, 2014: 71-72).

Diego asocia todas estas circunstancias con el nacimiento del Ultra que caracteriza a continuación:

"Ultra" significa una constante voluntad de renovación. El Ultra no tiene programa definido. Es un movimiento libre y plural; aspira a que en él se manifiesten todas las escuelas. El Ultra es, por consiguiente, invulnerable. La obra de sus adeptos podrá fracasar. El símbolo, la voluntad nunca. Díez-Canedo, el cultísimo crítico de la poesía moderna, ha dicho: "Todos los grandes poetas han sido ultraístas". Y es verdad. Pero si alguien cree que la palabra sobra, no es así. El ultraísmo es necesario para despertar a los dormidos y sacudir a los perezosos. Llámesele como se quiera, hacía falta este compromiso de voluntades. Porque el ultraísmo rompe en absoluto con la tradición. Rechaza todo lo que sea consecuencia o desarrollo de anteriores gérmenes y formas. En este sentido es plenamente negacionista, romántico, avanzado (2014: 72-73).

Es cierto que Rafael Osuna admite, siguiendo a Guillermo de Torre, que la orientación vanguardista de Cosmópolis «reside en los números 21 a 36» (2005: 105), pero no parece que se ajuste del todo a la realidad pues ese interés está ya presente en la primera entrega. El propio Cansinos publica en la segunda de Cosmópolis, en febrero de 1919, «El arte nuevo y sus manifestaciones entre nosotros», dedicado a Ramón Gómez de la Serna quien, tres años después, colaboró en el número 2 de Horizonte, el 30 de noviembre de 1922, con «Ramonismo» en que cifraba su estética. También Cansinos firma «La nueva lírica», en la quinta entrega de Cosmópolis de mayo de 1919, en que abunda en la aportación del creacionismo y la deuda de éste con la vanguardia francesa: 
La estética creacionista ha sido expuesta señaladamente por Max Jacob, en el prólogo a la segunda edición de su libro Le cornet à des. En este prólogo define el autor su teoría - c'est la theorir classique que je rapelle modestement - dice- del poema situado que no es más que el poema creado de Reverdy y Huidobro, y explica su interpretación del estilo — la voluntad de exteriorizarse por medio de elegidos, de la emoción artística- que es el efecto de una actividad pensante sobre una actividad pensada - y de la situación del poema- o sea su alejamiento respecto del sujeto-, algo parecido a la teoría de la sorpresa que preconizaba Baudelaire (74).

Cosmópolis también reprodujo el manifiesto del grupo Claridad, firmado entre otros por Anatole France, en el número 9, correspondiente a septiembre de 1919, que encierra unas palabras próximas a su propio ideario:

Trabajarán para preparar la República Universal, fuera de la cual no hay salud para los pueblos. Quieren la abolición de las barreras ficticias que separan los hombres, la aplicación integral de los catorce puntos wilsonianos, el respeto de la vida humana, el libre desenvolvimiento del individuo limitado sólo por las necesidades de la comunidad viviente; la igualdad social de todos, hombres y mujeres; la obligación de trabajar para todo ciudadano válido, el establecimiento del derecho de cada uno de ocupar en la sociedad el puesto que merezca por su labor, sus aptitudes o sus virtudes; la supresión del privilegio de nacimiento; la reforma, según los puntos de vista internacional, que es el punto de vista social absoluto, de todas las leyes que regulan la actividad humana: Trabajo, Comercia, Industria (171).

Antonio M. Cubero colaboró con «Literatura ultraísta», publicado en diciembre de 1919, en donde reivindica la novedad estética de la vanguardia: «El Ultraísmo es el carácter literario, la nueva voluntad libre, el allá misterioso que cada uno esculpe desde Su Yo pretérito y futuro. Es un vuelo desde la verdad de cuatro patas - (la ciencia, la moral, el academicismo, la historia, la erudición)- de libertad»(632-633). Cosmópolis se suma así en el año de 1919 a diferentes artículos y muestras vanguardistas aparecidos en diferentes revistas, que concluyen con la conferencia de Gerardo Diego. Rafael Cansinos Assens firma «Perspectivas. Algunas direcciones del nuevo arte: su reintegración lírica», para La correspondencia de España, en diciembre de 1918; Pedro Luis de Gálvez entregó en el número 14 de Grecia, en abril de 1919, «Marinetti. El estilo y el hombre»; el poema «Salomé», de Apollinaire, traducido por Enrique Díez-Canedo, aparecido en la misma revista en agosto de ese año correspondiente al número 24, motivo que interesó también a Cosmópolis que publicó el poema «Salomé» de Eugenio de Castro, traducido por Rufino Blanco Fombona, en la entrega duodécima en diciembre de 1919; Enrique Díez-Canedo publicó «Poetas modernos», en España, en el número 220 de junio de 1919; Gerardo Diego entregó a Cervantes «Anales literarios. Santander, literario», en junio de ese año; Guillermo de Torre traduce para el número 27 de Grecia, el 20 septiembre de 1919, el texto de Tristan Tzara, «Circuito total luna y color»; en octubre de 1919, Gerardo Diego publica en Cervantes «Posibilidades creacionistas».

No por azar se reprodujo «Una nueva escuela literaria. El manifiesto de los novecentistas», en el número 4 de Cosmópolis, en abril de 1919, incluido en la sección «Revistas y periódicos», firmado al calce por Xavier Bóveda, César A. Comet, Eliodoro Puche, Fernando Iglesias, Guillermo de Torre, Pedro Iglesias Caballero y Pedro Garfias; firme expresión de la fe de la juventud en una vanguardia en ciernes:

Nuestra literatura debe renovarse; debe lograr su ultra como hoy pretenden lograrlo nuestro pensamiento científico y político. 
Nuestro lema será ultra, y en nuestro credo cabrán todas las tendencias, sin distinción, con tal que expresen un anhelo nuevo. Más tarde, estas tendencias lograrán su núcleo y se definirán. Por el momento, creemos suficiente lanzar este grito de renovación y anunciar la publicación de una revista, que llevará este título de Ultra, y en la que sólo lo nuevo hallará acogida.

Jóvenes, rompamos por una vez nuestro retraimiento y afirmemos nuestra voluntad de superar a los precursores (765).

La proclama era trasunto de «Un manifiesto literario», publicado en el número 11 de marzo del mismo año en Grecia, rubricado por los mismos firmantes más J. Rivas Panedas y J. de Aroca.

La modernidad y el progreso asociado con la juventud era entonces un lugar común, impulsado igualmente por Cosmópolis, como recoge Paul Brulat en «La juventud literaria», aparecido en el número 6 de junio de 1919, que incluye unos principios próximos a la vanguardia en la medida que exalta lo nuevo y lo actual:

Por lo que se refiere a la literatura, resulta que un escritor permanece joven mientras no ha dicho cuanto tenía que decir, y su juventud es tanto más ardiente y más real, cuanto más precede a su época, anunciando o preparando tiempos nuevos o vislumbrando verdades que serán mañana. Entonces, y aun teniendo el sentimiento de pertenecer al pasado, puede sentirse joven por el corazón y el espíritu y aparecer como tal antes sus contemporáneos hasta la edad más avanzada (194).

En el número 20, correspondiente a agosto de 1920, Guillermo de Torre ya aparece como dueño de la sección «Literaturas novísimas» con la colaboración «La poesía creacionista y la pugna entre sus progenitores», en que informa de la querella entre Pierre Reverdy y Vicente Huidobro sobre la autoría del movimiento, a la vez que establece la influencia del cubismo en el creacionismo (589-605). En el número siguiente, publicó «Interpretaciones críticas de nueva estética», un breve ensayo sobre la importancia de la imagen en la poesía del momento, en particular, en el creacionismo:

Los poetas novísimos de hoy, perseguidos de módulos noviestructurales, manipulan básicamente en sus laboratorios plutónicos con un elemento eterno: la imagen. La imagen es el protoplasma primordial, la substancia celular del nuevo organismo lírico. La imagen es la dinamo motriz, suscitadora del circuito de sugerencias. Es el reactivo colorante de sus precipitados alquímicos. Y es, nuclearmente, el fijo coeficiente valorador de la ecuación poemática creacionista (89).

El mismo autor, dentro de la sección mencionada, entrega en el número 23 correspondiente a noviembre de 1923 «El movimiento ultraísta español», del que afirma que es una «juvenil y potencialísima tendencia de superación literaria ilimitada» (473). De Torre sitúa el nacimiento del movimiento en febrero de 1919, año en que se publicita desde la prensa madrileña el manifiesto, y de inmediato establece los vínculos con el creacionismo de Huidobro. Indica que el ultraísmo reaccionó frente al novecentismo como ya se había consignado en el manifiesto: «Declaramos nuestra voluntad de un Arte Nuevo que supla la última evolución literaria vigente en las modernas letras españolas, el novecentismo» (476-477). A continuación, refiere otros ismos con los que éste está en deuda:

Acogiendo así desde el Cubismo poético estructural de Apollinaire, Cendrars y Cocteau, hasta su emergencia teórica, el Creacionismo de Huidobro y Reverdy. Desde el Dadaismo funambulesco y caótico, ayer suizo, de Tzara y Picabia, hoy parisino de Ribemont-Dessaignes y Soupault y Breton, hasta el Expresionismo tudesco de Kurt Sechwiters, Heynicke y Klemm. Pasando por el Imaginismo inglés y norteamericano de Ezra Pound, Wallace Stevens, John Gould Flecchter... Y llegando en nuestra curiosidad 
sondeante y en nuestra cordialidad interpretativa hasta los denodados epígonos neo-futuristas, subsecuentes de Marinetti, como Mario Dessy, Mazza, Setimelli, Corra, Carli, etc. (481).

Guillermo de Torre no omite señalar las publicaciones comprometidas con el ultraísmo:

Nuestro ultraísmo literario ha tenido en los albores y tiene hoy su más puro órgano de expresión en la revista decenal Grecia, que nacida bajo la advocación rubeniana y helénica — de ahí su nombre-, ha efectuado un bello avatar transmutativo al evolucionar hacia el ultraísmo, merced al entusiasmo augural de su director, Vando-Villar, en la primavera de 1919, acogiendo las primicias de los primogénitos altruistas. $[\ldots]$

Otra gran revista de irradiación ultraica es Cervantes, más nutrida y polifacética -160 páginas en $8^{\circ}$, que dirigida por Cansinos Assens desde enero de 1919, ha recogido también valiosos brotes de la cosecha ultraísta [...] Como publicaciones efímeras, demostrativas empero de nuestro poder irradiante, están: Ultra, hoja literaria, aparecida en Oviedo, de octubre a diciembre de 1919, dirigida por Joaquín de la Escosura, y Perseo, en mayo del mismo año, lanzada en Madrid por Santiago Vera. Aisladamente otras revistas de Madrid, selectamente literarias, como España y Cosmópolis, han insertado o reproducido originales ultraístas, difundiendo nuestra tendencia (482-483).

Para terminar, el articulista registra la nómina de poetas ultraístas: Gerardo Diego, Eugenio Montes, Pedro Garfias, Jorge Luis Borges, Luciano de San-Sor (acrónimo de Lucía Sánchez de Saornil), J. Rivas Panedas, Ernesto López Parra, Juan Larrea, Joaquín de la Escosura, José de Ciria y Escalante, César A. Comet, Isaac del Vando-Villar, Rafael Lasso de la Vega, Adriano del Valle, Rafael Cansinos Assens resguardado tras el pseudónimo «Juan Las» y Guillermo de Torre. En el número 25, de enero de 1921, publica de Torre «El movimiento Dadá», en que subraya su carácter antiacademicista: «pues la gesta DADÁ, sus alaridos heresiarcas y sus muecas subversivas no han ido dirigidas estrictamente contra el público pasivo, sino más bien contra los letrados retardatarios y las larvas del tradicionalismo insolvente» (161). Pero el crítico se limita a los orígenes del dadaísmo y a su efímera presencia en el panorama literario y cultural hasta transformarse en 1919 en «un conglomerado amorfo de varias tendencias insurgentes y superatrices, dirigidas a rebasar la meta de los últimos movimientos artísticos» (169). Es en la siguiente entrega, cuando Guillermo de Torre publica «Gestos y teorías de dadaísmo», donde distingue entre éste y el cubismo sin olvidar apuntar sus semejanzas. Escribe que

[...] lo esencial de las innovaciones cubisto-dadaístas, arranca de futurismo marinettiano. En efecto, a primera vista, los medios exteriores de propaganda y réclame que usan futuristas y dadaístas, son fraternalmente semejantes: actitud rebeliosa e insolente ante los auditorios y lectores, buscando la réplica recíproca y producción numerosa del adorno teórico esparcido en múltiples manifiestos y publicaciones que van delimitando el alcance, mutaciones y repercusiones sucesivas de su tendencia (348).

De alguna manera, este artículo complementaba el ensayo aparecido dos números antes, en el 24 de diciembre de 1920, en la sección «Estudios cosmopolitas», elaborado por Rafael Lasso de la Vega, titulado «La sección de oro», en que establece las relaciones entre creacionismo, dadaísmo y cubismo como exponentes de la vanguardia alentado por la colaboración de Guillermo de Torre «El movimiento ultraísta español»: «Entre esas escuelas está, en primer término, el creacionismo, que en realidad se comunica con las demás escuelas d'avant-garde, ya que todas tienden a crear un arte puro, independiente y propio, dentro de la áurea sección»(642). Este texto privilegia el movimiento creacionista por encima de sus predecesores e incide en los antecedentes simbolistas. Para Lasso de la 
Vega, el cubismo en 1920 es una expresión agotada, a diferencia del dadaísmo significado por su «actitud sarcástica», por eso «el creacionismo no podía seguir un camino conformable con el cubismo. El problema es el esencialismo y consiste en que se desenvuelven en planos que, aunque equivalentes, son distintos: Espacio y tiempo» (647). La siguiente colaboración de Guillermo de Torre, «El vórtice dadaísta», aparece en el número 27 de marzo de 1921. Allí, el español revisa la literatura crítica sobre el dadaísmo, como también los elementos que toma de la tradición literaria francesa (416-439). Así mismo, publicó en mayo de 1921, número 29, dentro de «Literaturas novísimas» la colaboración «Ultra-manifiestos», que reúne «Estética del yoísmo ultraísta»e «Invitación a la blasfemia» (51-61).

En agosto de 1921, correspondiente al número 32, Guillermo de Torre colabora con «Problemas teóricos y estética experimental del nuevo lirismo», donde propone una interpretación de los ismos, en particular del creacionismo, a partir del texto de Jean Epstein, Poésie d'aujord'hui. Más interesante es el texto del mismo autor, publicado en la entrega 33 de septiembre de 1921, «El cinema y la novísima literatura: sus conexiones», fuera de su sección habitual, en que saluda con alborozo al nuevo arte: «el Cinema aspira a devenir [...] el Arte sintético, muscular, íntegro, dinámico y netamente expresivo de nuestra época acelerada y vorticista» (97). Para de Torre, hay una «conexión recíproca» entre «el film accional y sintético, y el poema cinemático, merced a sus rasgos comunes más esenciales: esquemático por sus líneas envolventes, fotogénico por la irradiación de su verbo estelar y acelerado en su vibración multiplanista» (100). Ambos lenguajes coinciden en que «del mismo modo que en la nueva poesía, en el film perfecto se propende a la tensión del conjunto armónico, suprimiendo los convencionalismos ralentisseurs, para depurar la emoción expectante, y la belleza fotogénica» (102); uno y otro, además, tienden a la síntesis:

[...] la ausencia del simbolismo, de alegóricas comparaciones literarias y ejemplos moralistas o tendenciosos se percibe gratamente en los films que aspiran a ser puramente cinemáticos. Del mismo modo, en la nueva poesía propendemos ante todo a la reintegración lírica, separándola de los géneros narrativo y descriptivo, y dotando al poema de una corporeidad propia y vida peculiar (106).

Para Guillermo de Torre, las «metáforas visuales» exhiben esa comunión entre cine y poesía:

El valor visual - sistema tipográfico de blancos y espacios- que las nuevas normas estéticas conceden al poema, por encima del valor auditivo, que antes poseía, en la era de las sonoras orquestaciones retóricas, hoy abolidas, se manifiesta paralelamente en el Cinema, donde la concatenación argumental debe hallarse subordinada a la armonía estética de los planos fotográficos (106).

Más adelante, en diciembre de 1921, entrega 36, el mismo crítico le dedica a la vanguardia el artículo «Los poetas cubistas franceses. Síntesis crítica» que, como indica el subtítulo es un resumen ajustado de la crítica sobre este movimiento. Repara Guillermo de Torre en la denominación «cubista» aplicada a un grupo de poetas, entre los que se encuentran Apollinaire, Salmón, Gleizes, Raynal, Rosenberg y Cocteau, que se debe «a más de su tangencialidad ideológica, un nexo de coetaneidad con los pintores cubistas: son sus compañeros en las esforzadas gestas de los albores» (604).

Con la llegada de Hernández Catá a la dirección, la revista perdió el temperamento adquirido bajo la tutela de Gómez Carrillo. Sin embargo, la ruptura no fue abrupta pues conserva algunas 
secciones y también a colaboradores de la etapa anterior. Guillermo de Torre pierde su sección, pero no deja de aportar escritos casi siempre referidos a las vanguardias literarias. Así, el número 39 de marzo de 1922, publica «Valoración estética de los elementos modernos», cuya tesis es la afirmación de los elementos y factores del progreso como cauce para una expresión poética moderna:

La descripción o referencia de máquinas, aviones, dreadgnoughts, antenas telegráficas, auriculares telefónicos, reflectores, locomóviles ebrios de espacio, hangar, embarcaderos y de los múltiples elementos que nos ofrece la vida en la calle contorsionada, el music-hall o desde la terraza de un rascacielos: todo ello no significa una supeditación espiritual a las radiaciones absorbentes de tales elementos, sino una utilización directa de las fuerzas que atesoran, y una ejemplificante lección para el espíritu de su ritmo y de su sentido vital (54-55).

Propone el autor que las pugnas entre las diferentes vanguardias poco tienen que ver con la modernidad y, más bien, son expresiones interesadas en el reconocimiento de una supuesta originalidad propia, aunque advierte diferencias:

La exposición de las anteriores teorías demuestra que el problema de imposición y valoración de os elementos modernos gira en torno a la pugna establecida entre los futuristas, partidarios de aportar al arte los valores coetáneos, frente a los cubistas y afines que, empero estar movidos por anhelos innovadores, desdeñan la entronización y persisten en utilizar exclusivamente los recursos tradicionales (57).

Concluye de Torre urgiendo a «identificarse con los nuevos elementos, asimilarse su ejemplificante ritmo, hacer intervenir como personajes vivientes sus fuerzas: Ahí radica el punto nuclear para la interpretación y evaluación de lo moderno» (58). Posteriormente, Guillermo de Torre entrega «Paul Morand, cosmopolita y cinemático», incluido en lo que presumiblemente era una nueva sección denominada «Interpretaciones y sugerencias». Publicado en el número 44 de agosto de 1922, el autor destaca aquello que considera novedoso de la prosa de Morand: «Aquí, en los libros de Morand, ni paisajes orientalistas ni determinación de las coordenadas. La realidad, la vida inmediata y saltante, cazada con ojos de arquero en su esencialidad cinemática y estructurada, según la planimetría cubista» (324). Le sigue «El detective espiritual o la obsesión del psicoanálisis», publicado en el número 44 correspondiente a agosto de 1922, como es habitual bajo la lupa de Epstein, se centra en los errores de lenguaje por parte del hablante, por lo que postula que

[...] nos lleva a vigilar los hechos de nuestra inevitable y subcutánea psicopatología de la vida cotidiana. Nos convertimos en espías de nosotros mismos, analizando y desmenuzando hasta sus raíces primarias y causas últimas nuestros actos fallidos, los frecuentes lapsus momentáneos al saber que estos son actos psíquicos completos que tienen su fin, su contenido y su significación propias (327).

En el texto titulado «Los espejos curvos de un humorista forzado», publicado en la misma entrega, el crítico advierte el humor del momento relacionado con el valleinclanesco espejo curvo, pero eta vez en alusión al practicado por Cansinos Assens en su obra El movimiento V. P.: «El satírico moderno, en vez de esgrimir el látigo juvenalicio, porta en sus manos un espejo curvo. Pero este espejo, donde aspira a recoger la realidad maleada, rara vez es ecuánime y objetivo» (329).

La invectiva está dirigida a Cansinos quien en la novela citada arremete contra los ultraístas. Por eso comenta Guillermo de Torre que «sabido es que el nexo espiritual de este autor con el sector 
ultraísta, debíase a la posición crítica que sostuvo como turiferario inicial y alentador teórico de este movimiento juvenil» (330), de manera que la crítica vertida en El movimiento $V$. P. se debe según el crítico a que Cansinos «ha variado de actitud espiritual enfocadora, comenzando a percibir reflejos cómicos y refracciones caricaturales, donde antes sólo veía siluetas simpáticas y nobles rasgos espirituales, dignos de loa y exaltación» (330). Como consecuencia, de Torre tilda esta obra de «farsa que, si al principio ofrece algún nexo de enlaces recognoscibles, después entra francamente en el reino de lo ilusorio, se eleva a la cuarta región del disparate, donde la imaginación traza solo cabriolas regocijantes por el puro placer de rasgar paisajes cómicos de posibilidades imaginarias» (331-332). El último ensayo de Guillermo de Torre se titula «El renacimiento xilográfico. Tres grabadores ultraístas», publicado en agosto de 1922, número 44, sobre el uso y la utilidad de la madera para ese quehacer

[...] porque al manumitirse de la tarea inicial pseudo fotográfica, adquiere categoría de arte nuevo y fragante, deviniendo medio favorito de los artistas vanguardistas extranjeros, al perforar la dura calidad de la materia y hallan esas severas estructuraciones, que revelan su tangencialidad espiritual con los módulos del arte negro y oceánico... (334).

Como es frecuente, el autor aprovecha para situar en un lugar muy visible a los artistas ultraístas, como la argentina Norah Borges, el uruguayo Rafael Barradas y el polaco Wladyslaw Jahl, cuyos grabados ilustran las publicaciones del movimiento como Grecia, Tableros, Ultra y Reflector.

\section{Conclusión}

Cosmópolis representa de manera cabal la definición del modernismo consignada por Juan Ramón Jiménez, que desde luego no es la única, ni seguramente la más decisiva, sino una más, pero de la que no podemos hacer caso omiso y que, en todo caso, es tan importante como otras. Octavio Paz indica que Juan Ramón exagera al afirmar "que las distintas y contrarias escuelas que sucedieron al modernismo no fueron en realidad sino variaciones de este último" y, también, "al decir que el movimiento poético moderno, en toda su contradictoria diversidad, es una mera consecuencia del modernismo; no lo es afirmar que éste es un momento, el inicial, de la modernidad" (1993: 89). La revista encierra una ironía trágica, porque algunos colaboradores bohemios poco tuvieron de cosmopolitas. Sin embargo, la publicación se mantuvo fiel, hasta la renuncia de Enrique Gómez Carrillo, a la pervivencia del cosmopolitismo finisecular, sobre todo modernista; las secciones de Cosmópolis bajo la dirección del guatemalteco así lo certifican. Pero en ningún caso puede afirmarse que la revista no se interese por la nueva literatura o las novísimas literaturas o la vanguardia literaria. Al contrario, desde el primer número esta curiosidad y esta atención aparecen de manera muy visible. Cosmópolis no sólo publicó ensayos y estudios sobre la vanguardia europea y española, acerca del dadaísmo, futurismo, cubismo y ultraísmo, sino que exhibió en sus páginas muestrarios de la nueva literatura, así como promocionó a sus autores más significativos. Desde luego, no fue tan militante o su adhesión no fue tan determinante como la de Cervantes, Grecia o, poco después, Ultra, pero no hay duda de que su aportación en ese momento resultó decisiva como demuestra el hecho de que algunos 
de sus colaboradores más representativos militaran entonces en el ultraísmo como Guillermo de Torre, Rafael Cansinos Assens, Rafael Lasso de la Vega, etcétera. Cosmópolis es un termómetro fiel de la temperatura literaria de España a principios de la tercera década del siglo XX, un escaparate que exhibe los diferentes modos de entender y hacer literatura en que la vanguardia adquiere un protagonismo incuestionable.

\section{Referencias bibliográficas}

A. P. (mayo de 1920): “La literatura provenzal”, Cosmópolis, 17, pp. 1-15. ANÓNIMO (enero de 1919): "Las figuras del día”, Cosmópolis, 1, p. 168.

_ (febrero de 1919): "La vida femenina”, Cosmópolis, 2, p. 232. (febrero de 1919): “Crónica americana”, Cosmópolis, 2, p. 315.

— (febrero de 1919): "Fisonomías de ciudades después de la guerra", Cosmópolis, 2, p. 354.

— (diciembre de 1919): "Venecia y sus pintores”, Cosmópolis, 12, pp. 645-650.

_ (julio de 1920): “La nueva literatura alemana”, Cosmópolis, 19, pp. 403-414.

—_ (agosto de 1920): "La nueva literatura alemana”, Cosmópolis, 20, pp. 661-666.

__ (septiembre de 1920): “La nueva literatura alemana”, Cosmópolis, 21, pp. 1-6.

— (1 de septiembre de 1920): "Panorama ultraísta", Grecia, 48, pp. 15-16.

ApollinAIRE, Guillaume (enero de 1919): "El espíritu nuevo y los poetas”. Cosmópolis,1, pp. 17 28.

— (10 de agosto de 1919): "Salomé", trad. Enrique Díez-Canedo, Grecia, 24, p. 8.

APPIAH, Kwame Anthony (2007): Cosmopolitismo. La ética en un mundo de extraños. Trad. Lilia Mosconi. Buenos Aires, Katz.

ASTERIOTIS, Demetrius (junio de 1920): "El nuevo helenismo", Cosmópolis, 18, pp. 221-228.

BAUdElaIRE, Charles (octubre de 1921): “Antología francesa”, Cosmópolis, 34, pp. 321-326.

— (noviembre de 1921): “Antología francesa”, Cosmópolis, 35, pp. 392-394.

- (2005): Salones y otros escritos sobre arte. Introd. Guillermo Solana y trad. Carmen Santos. Madrid, Machado Libros.

Bonet, Juan Manuel (2012): Las cosas se han roto. Antología de poesía ultraísta. Sevilla, Fundación José Manuel Lara.

BóvedA, Xavier et al. (15 de marzo de 1919): "Un manifiesto literario", Grecia, 11, p. 11. (abril de 1919): "Una nueva escuela literaria. El manifiesto de los novecentistas", Cosmópolis, 4, pp. 764-765.

BRUlat, Paul (junio de 1919): “La juventud literaria”, Cosmópolis, 6, pp. 193-196.

CAnsinos Assens, Rafael (1 de diciembre de 1918): "Perspectivas. Algunas direcciones del nuevo arte: su reintegración lírica", La correspondencia de España, p. 4.

- (enero de 1919): "Un gran poeta chileno, Vicente Huidobro y el creacionismo". Cosmópolis, 1, pp. 68-73. 
_ (febrero de 1919): "El arte nuevo y sus manifestaciones entre nosotros", Cosmópolis, 2, pp. 262-267.

_ (mayo de 1919): “La nueva lírica”. Cosmópolis, 5, pp. 72-80.

(diciembre de 1920): "Vertical: Manifiesto ultraísta por Guillermo de Torre", Cervantes, pp.

115-121.

(1998): Obra crítica. T. II. Sevilla, Diputación de Sevilla.

CAstro, Eugenio de (diciembre de 1919): "Salomé”, trad. Rufino Blanco Fombona, Cosmópolis, 12, pp. 701-708.

Cubero, Antonio M. (diciembre de 1919): “Literatura ultraísta”, Cosmópolis, 12, pp. 632-633.

DIEGO, Gerardo (junio de 1919): “Anales literarios. Santander, literario”, Cervantes, pp. 56-77.

(octubre de 1919): "Posibilidades creacionistas", Cervantes, pp. 23-28.

(1919): La poesía nueva. (La conferencia y la polémica, 1919). Ed. Juan Manuel Díaz de Guereñu. Madrid, Residencia de Estudiantes, 2014.

DíEZ-CANEDO, Enrique (26 de junio de 1919): "Poetas modernos", España, 220, p. 10.

FERnÁNDEZ MEDinA, B. (3 de marzo de 1919): “El Uruguay”, Cosmópolis, 3, pp. 407-422.

FRANCE, Anatole et al. (septiembre de 1919): "Manifiesto del grupo Claridad", Cosmópolis, 9, pp. 169-172.

FUENTE, Ricardo de la (2009): "Introducción”, en Enrique Gómez Carrillo, Esquisses. San Luis Potosí, El Colegio de San Luis, pp. 7-42.

GÁlvEZ, Pedro Luis de (30 de abril de 1919): "Marinetti. El estilo y el hombre”, Grecia, 14, p. 7.

García Kohl, M. (abril de 1919): “Cuba en 1919”, Cosmópolis, 4, pp. 625-642.

GARFIAS, Pedro (mayo de 1919): "La fiesta del Ultra", Cervantes, pp. 76-80

GAUCHEZ, Maurice (octubre de 1919): "La poesía nueva en Bélgica”, Cosmópolis, 10, pp.193-202.

Gómez CarriLlo, Enrique (1892): Esquisses. Ed. Ricardo de la Fuente. San Luis Potosí, El Colegio de San Luis, 2009.

- (enero de 1919): "La escuela de periodismo", Cosmópolis, 1, pp. 112117.

(diciembre de 1919): "La psicología del viaje”, Cosmópolis, 12, pp. 610-631.

(febrero de 1920): “Treinta años de mi vida, (Segunda parte)”, Cosmópolis,14, pp. 1-22.

(marzo de 1920): “Treinta años de mi vida, (Tercera parte)", Cosmópolis, 15, pp. 218-228.

(abril de 1920): "Treinta años de mi vida", Cosmópolis, 16, pp. 471-481.

(mayo de 1919): "Treinta años de mi vida", Cosmópolis, 17, pp. 55-69.

(junio de 1920): “Treinta años de mi vida", Cosmópolis, 18, pp. 285-296.

_ (julio de 1920): “Treinta años de mi vida”, Cosmópolis, 19, pp. 513-523.

(2011): Treinta años de mi vida. Pról. José Luis García Martín. Renacimiento, Sevilla.

GÓMEZ DE LA SERNA, Ramón (30 de noviembre de 1922): "Ramonismo”, Horizonte, 2, p. 1.

GonzÁlez RuAno, César (2004): Memorias. Mi medio siglo se confiesa a medias. Sevilla, Renacimiento.

GuÉRIN, Charles (diciembre de 1919): “Antología francesa”, Cosmópolis, 12, pp. 634-638. 
HAZARD, Paul (1946): El pensamiento europeo del siglo XVIII. Trad. Julián Marías. Madrid, Revista de Occidente.

HÉctoR (enero de 1919): “A través de las revistas”, Cervantes, 21, pp. 186-189.

__ (mayo de 1921): “A través de las nuevas revistas”, Cosmópolis, 29, pp. 165-170.

HogGAN, F. (abril de 1920): “La literatura y el arte negros”, Cosmópolis, 16, pp. 385-399.

JAMMES, Francis (abril de 1919): "Poesías de Francis Jammes", Cosmópolis, 4, pp. 660-663

JiMÉNEZ, Juan Ramón (2010): El Modernismo (1953). Obras. Pról. Luis Alberto de Cuenca. Madrid, Visor-Diputación de Huelva.

KLINGSOR, Tristan (mayo de 1920): “Antología francesa”, Cosmópolis, 17, pp. 24-27.

LAFORGUE, Jules (abril de 1920): “Antología francesa”, Cosmópolis, 16, pp. 432-436.

LASSO DE LA VEGA, Rafael (noviembre de 1920): "Vertical: Manifiesto ultraísta", Cosmópolis, 23, pp. 551-552.

— (diciembre de 1920): "La sección de oro", Cosmópolis, 24, pp. 642-667.

LERBERGHe, Charles van (febrero de 1920): “Antología francesa”, Cosmópolis, 14, pp. 117-120.

LITVAK, Lily (1986): El sendero del tigre. Exotismo en la literatura española de finales del siglo XIX, 1880-1913. Madrid, Taurus.

Loewengard, Paul (junio de 1919): "El renacimiento de la literatura judía”, Cosmópolis, 6, pp. 298-305.

LóPeZ LAPUYA, Isidoro (2001): La bohemia española en París a fines del siglo pasado. Sevilla, Renacimiento.

MAETERLinK, Maurice (enero de 1919): “Gómez Carrillo, juzgado por Maeterlink”, Cosmópolis, 1, pp. 159-161.

— (agosto de 1919): “Antología francesa de Maurice Maeterlinck”, Cosmópolis, 8, pp. 690693.

MALlarmé, Stéphane (febrero de 1919): "Poesías de Mallarmé”, Cosmópolis, 2, pp. 342-346.

MERRILL, Stuart (marzo de 1920): “Antología francesa”, Cosmópolis, 15, 257-259.

MorÉAs, Jean (marzo de 1919): "Poesía de Jean Moréas”, Cosmópolis, 3, pp. 562-566.

Neuhuys, Paul (abril de 1922): "La nueva poesía en Bélgica”, Cosmópolis, 40, pp. 58-63.

NoGales, José (octubre de 1919): "El encanto de Sevilla", Cosmópolis, 10, pp. 213-232.

(noviembre de 1919): "El encanto de Sevilla", Cosmópolis, 11, pp. 422-440.

ORTEGA, Juan J. (mayo de 1919): “Guatemala en 1914”, Cosmópolis, 5, pp. 5-13.

O’Sullivan, Vincent (mayo de 1919): "La literatura norteamericana”, Cosmópolis, 5, pp. 60-71. (noviembre de 1919): “La literatura norteamericana”, Cosmópolis, 11, pp. 401-415.

OsunA, Rafael (2005): Revistas de la vanguardia española. Sevilla, Renacimiento.

PAZ, Octavio (1993): Obras completas, t. 3, México: FCE.

PHILliPs, Allen W. (1959): “Rubén Darío y sus juicios sobre el Modernismo", Revista Iberoamericana, 24, pp. 53 -58.

PRitchetT, V. S. (2011). El viaje literario. Cincuenta ensayos. Trad. Ramón García. México, FCE. REDACCIÓN (septiembre de 1920): “Advertencia”, Cosmópolis, 21, p. 2. 
RÉVÉSZ, Andrés (septiembre de 1919): “El movimiento literario en Hungría”, Cosmópolis, 9, pp. $1-9$.

RiCHEPIN, Jean (diciembre de 1920): “Antología francesa”, Cosmópolis, 24, pp. 771-776.

Rimbaud, Arthur (junio de 1919): “Poesías de Arthur Rimbaud”, Cosmópolis, 6, pp. 295-297.

RoDENBACH, Georges (noviembre de 1919): “Antología francesa”, Cosmópolis, 11, pp. 416-421.

Rostand, Edmond (julio de 1920): “Antología francesa”, Cosmópolis, 19, pp. 457-466.

SAMAIN, Albert (mayo de 1919): "Poesías de Albert Samain”, Cosmópolis, 5, pp. 110-112.

SPETH, William (julio de 1919): “La literatura belga”, Cosmópolis, 7, pp. 390-399.

TORRE, Guillermo de (agosto de 1920): "La poesía creacionista y la pugna entre sus progenitores", Cosmópolis, 20, pp. 589-605.

— (septiembre de 1920): "Interpretaciones críticas de nueva estética", Cosmópolis, 21, pp. 89 96.

— (noviembre de 1920): "El movimiento ultraísta español”, Cosmópolis, 23, pp. 473-495.

— (1 de noviembre de 1920): "Vertical", Grecia, 50, s. p.

— (enero de 1921): "El movimiento Dadá”, Cosmópolis, 25, pp. 160-169.

— (febrero de 1921): “Gestos y teorías de dadaísmo”, Cosmópolis, 26, p. 339-352.

—_ (marzo de 1921): "El vórtice dadaísta”, Cosmópolis, 27, pp. 416-439.

—_ (mayo de 1921): "Ultra-Manifiestos", Cosmópolis, 29, pp. 51-61.

— (agosto de 1921): "Problemas teóricos y estética experimental del nuevo lirismo", Cosmópolis, 32, pp. 585-607.

_ (septiembre de 1921): "El cinema y la novísima literatura: sus conexiones”, Cosmópolis, 33, pp. 97-107.

— (diciembre de 1921): "Los poetas cubistas franceses. Síntesis crítica”, Cosmópolis, 36, pp. 603-626.

—_ (marzo de 1922): "Valoración estética de los elementos modernos", Cosmópolis, 39, pp. 5258.

(agosto de 1922): "Paul Morand, cosmopolita y cinemático", Cosmópolis, 44, pp. 324-326. (agosto de 1922): "El detective espiritual o la obsesión del psicoanálisis", Cosmópolis, 44, pp. 327-328.

(agosto de 1922): "Los espejos curvos de un humorista forzado", Cosmópolis, 44, p. 329333.

(agosto de 1922): "El renacimiento xilográfico. Tres grabadores ultraístas”, Cosmópolis, 44, pp. 333-336.

- (1969): Del 98 al Barroco. Madrid, Gredos.

(2001): Historia de las literaturas de vanguardia. Madrid, Visor.

TZARA, Tristan (20 de septiembre de 1919): "Circuito total luna y color", trad. Guillermo de Torre, Grecia, 27, pp. 5-6.

VANDO VILlar, Isaac del (30 de junio de 1919): "Manifiesto ultraísta", Grecia, 20, p. 9. - (12 de octubre de 1919): "El triunfo del ultraísmo”, Grecia, 29, pp. 1-2. 
328 Tropelías. Revista de Teoría de la Literatura y Literatura Comparada, 30 (2018) Juan Pascual Gay

VERHAEREN, Emile (septiembre de 1919): “Antología francesa”. Cosmópolis, 9, pp. 43-48.

Verlaine, Paul (junio de 1920): “Antología francesa”, Cosmópolis, 18, pp. 247-260.

VIÉLÉ-GrifFIn, Francis (agosto de 1920): “Antología francesa”, Cosmópolis, 20, pp. 606-609.

WILDE, Oscar (enero de 1919): “Seis poemas inéditos de Oscar Wilde”, Cosmópolis, 1, pp. 142152. 